Jurnal

\title{
Higher Plasma Glucose Level In Hypertensive Patient With Angiotensin Converting Enzyme Gene Deletion Of Intron 16
}

\author{
Lowry Yunita' ${ }^{1}$, Mohammad Saifur Rohman, Bagus H Kuncahyo', Mifetika Lukitasari², \\ Arina Madjidi', Maulidiyatun Nuril Faizah³ ${ }^{1}$ Nashi Widodo ${ }^{3}$
}

I. Departement of Cardiology and Vascular Medicine, Faculty of Medicine,

Brawijaya University-Saiful Anwar General Hospital

2. Department of Nursing, Faculty of Medicine,

Brawijaya University-Saiful Anwar General Hospital

3. Departement of Biology, Faculty of Mathematic and Science, Brawijaya University

Email : ippoenk@yahoo.com
Background Renin Angiotensin Aldosteron System plays major role in hypertension pathophysiology. Has been proposed that half of individuals with essential hypertension are considered insulin resistant. Angiotensin Converting Enzyme gene polymorphism taking the control of ACE level in human plasma. There might be a correlation between ACE gene polymorphism and plasma glucose level.

Objective This study sought to investigate ACE gene polymorphism insertion/deletion in hypertensive patients and its correlation with plasma glucose level.

Method A total of 100 hypertensive patients at Saiful Anwar cardiovascular outpatients clinic who received ACEi at least 8 weeks were included. ACE genotype were determined by polymerase chain reaction method, and plasma glucose level was measured by enzymatic colorimetric assay method.

Result The II, ID, and DD genotype were observed in $48 \%, 29 \%$ and $23 \%$ of participant, respectively. The fasting and 2 hours post prandial plasma glucose were significantly higher in DD genotype patients. The insertion/ deletion polymorphisms were not related significantly to age, sex, cough, and controlled blood pressure of those patients.

Conclusion This study showed that $23 \%$ of hypertensive patients had DD genotype with higher plasma glucose level as compare to those of II and ID genotype.

(J Kardiol Indones. 2016;37:13-8)

Keywords: angiotensin converting enzyme gene, polymorphism insertion/ deletion, plasma glucose level. 
Jurnal

Kardiologi Indonesia

J Kardiol Indones. 2016;37:13-8

ISSN 0I26/3773

\title{
Kadar Gula Darah Lebih Tinggi pada Pasien Hipertensi dengan Delesi Intron 16 Gen Ace
}

\author{
Lowry Yunita', Mohammad Saifur Rohman, Bagus H Kuncahyo', Mifetika Lukitasari², \\ Arina Madjidi', Maulidiyatun Nuril Faizah³, Nashi Widodo ${ }^{3}$
}

\begin{abstract}
Latar Belakang : Sistem Renin Angiotensin Aldosteron berperan penting dalam hipertensi. Telah diperkirakan bahwa separuh dari pasien dengan hipertensi primer memiliki resistensi terhadap insulin. Polimorfisme gen Angiotensin Converting Enzyme (ACE) dianggap bertanggung jawab terhadap kadar ACE dalam plasma. Diprediksi terdapat hubungan antara polimorfisme gen ACE dengan tingginya kadar gula pada pasien hipertensi.

Tujuan : Mempelajari hubungan antara polimorfisme gen ACE dengan kadar gula darah pada pasien hipertensi.

Metode : Sebanyak 100 pasien hipertensi dari Poli Jantung Rumah Sakit dr.Saiful Anwar Malang yang menerima terapi dengan penghambat ACE selama 8 minggu diambil darahnya untuk dianalisis polimorfisme gen ACE serta dilakukan pengukuran kadar gula darah.

Hasil : Genotip II, ID, dan DD ditemukan sebesar 48\%, 29\% and 23\% masing-masing Kadar gula darah puasa dan 2 jam sesudah makan lebih tinggi signifikan pada kelompok pasien dengan genotip DD. Sedangkan terhadap usia, jenis kelamin, dan terkontrolnya tekanan darah tidak ditemukan hubungan dengan polimorfisme gen ACE.

Kesimpulan: 23\% pasien hipertensi dengan genotip DD memiliki gula darah yang lebih tinggi dibanding genotip II dan ID.
\end{abstract}

(J Kardiol Indones. 2016;37:13-8)

Kata kunci : gen angiotensin converting enzyme gene, insersi/delesi, kadar gula darah

\section{Pendahuluan}

A CE memiliki peranan penting dalam sistem kardiovaskular termasuk hipertensi. ${ }^{1}$ Penelitian yang ada sebelumnya menemukan bahwa aktivitas ACE dipengaruhi oleh polimorfisme gen $\mathrm{ACE}^{2}$, yang ditandai oleh keberadaan (insersi, I) atau ketiadaan (delesi, D) sebanyak

\section{Alamat Korespondensi}

dr.Lowry Yunita, Departemen Kardiologi dan Kedokteran Vaskular, Fakultas Kedokteran Universitas Brawijaya - Rumah Sakit Umum dr.Saiful Anwar. E-mail: ippoenk@yahoo.com
287 pasang basa pada intron 16 dan kromosom 17 q23 dari gen ACE. ${ }^{3}$ Sebuah penelitian metaanalisis menyebutkan distribusi genotip II dan genotip DD berbeda bermakna diantara populasi hipertensi di Asia (II : 36.4\%, DD: 16.3\%) dibandingkan populasi hipertensi di Kaukasia ( II : 24.9\%, DD : 28.6\%). ${ }^{4}$

Data di populasi Kaukasia menunjukkan bahwa kadar ACE di plasma berhubungan dengan polimorfisme gen ACE, dengan kadar tertinggi pada kelompok genotip DD dan yang terendah adalah kelompok genotip II. Kadar ACE plasma memiliki keterkaitan dengan kadar kolesterol, kadar gula plasma, dan tekanan darah. ${ }^{5}$ Data mengenai korelasi antara 
polimorfisme gen ACE insersi/delesi dengan kadar gula plasma di Indonesia belum memadai. Untuk itu studi ini bertujuan untuk mempelajari hubungan antara polimorfisme gen ACE dengan kadar gula darah pada pasien hipertensi.

\section{METODE}

\section{Subjek dan material}

Penelitian ini diadakan di RS.dr.Saiful Anwar Malang selama Juni 2013 - September 2014. 100 pasien hipertensi usia $>40$ tahun yang berobat ke poli jantung RSSA terlibat dalam penelitian ini. Seluruhnya mendapat terapi dengan penghambat ACE dengan fungsi ginjal normal (kreatinin serum $<2.5 \mathrm{gr} / \mathrm{dL}$ ). Pasien dengan hipertensi sekunder, penyakit paru (infeksi, COPD), gagal jantung kongestif, diabetes mellitus dieksklusi. Setelah terapi penghambat ACE selama 8 minggu, dilakukan pengambilan sampel darah vena untuk analisis polimorfisme dan pengukuran kadar gula, kolesterol, dan fungsi ginjal; serta dilakukan pengukuran tekanan darah ambulatori selama 24 jam menggunakan ABPM (twenty four hours ambulatory blood pressure monitoring).

\section{Analisis Polimorfisme}

Amplifikasi DNA dilakukan menggunakan metode Polymerase Chain Reaction (PCR). Primer yang digunakan adalah forward 5'-GCCCTGCAGGTGTCTGCAGCATGT-3' dan reverse 5'-GGATGGCTCTCCCCGCCTTGTCTC-3'. Komposisi larutan PCR dengan volume total $20 \mu \mathrm{l}$, terdiri atas $4 \mu \mathrm{dddH} 2 \mathrm{O}, 10$ $\mu \mathrm{l}$ PCR mix (Master Mix Kit Intron), $2 \mu \mathrm{l}$ DNA whole genome, dan primer $\mathrm{F}$ dan $\mathrm{R}(20 \mathrm{pmol})$ masing-masing $2 \mu \mathrm{l}$. Kondisi PCR yang digunakan adalah predenaturation $95^{\circ} \mathrm{C}$ selama 5 menit, denaturation $96^{\circ} \mathrm{C}$ selama 45 detik, annealing $60.3^{\circ} \mathrm{C}$ selama 45 detik, extention $72^{\circ} \mathrm{C}$ selama 45 detik, post-extention $72^{\circ} \mathrm{C}$ selama 10 menit. Dilakukan pengulangan sebanyak 34 siklus. Amplikon target sebesar 599 pb (allele insersi) dan 312 pb (allele delesi).

Produk PCR dideteksi dengan cara dimigrasikan pada gel agarosa $2 \%$. Dalam TBE $1 \mathrm{x}$, kemudian dipanaskan sampai mendidih, ditambahkan etidium bromida (EtBr) sebanyak1 $\mu$ l. Setelah itu agarosa dituang ke dalam cetakan yang telah disiapkan, dipasang sisir sesuai dengan jumlah sampel dan dibiarkan hingga membeku selama 50 menit. Gel yang telah membeku lalu direndam dalam piranti elektroforesis yang telah diisi buffer TBE 1x. Sebanyak $4 \mu \mathrm{l}$ sampel dimasukkan ke dalam sumur sampel (agarosa). Elektroforesis dilakukan dengan Submarine Electrophoresis (Hoeffer USA) dengan voltase $100 \mathrm{~V}$ selama 30 menit. Hasil elektroforesis diamati dengan geldoc 300nm UV Transilluminator. Adanya produk PCR ditunjukkan dengan adanya pita (band) dalam gel hasil elektroforesis.

\section{Pengukuran Kadar Gula Darah}

Sampel darah diambil setelah mendapat terapi dengan penghambat ACE. Kadar gula plasma diukur menggunakan metode enzymatic colorimetric assay.

\section{Data Analisis}

Data kontinyu diekspresikan sebagai mean \pm SD. Uji beda menggunakan two-sided unpaired $t$ test dan $\mathrm{X}^{2}$ test. Analisa statistik mennggunakan SPSS 18 (SPSS Inc). Nilai $p<0.05$, 2-tailed, dianggap signifikan secara statistik.

\section{Hasil}

Dari 100 sampel hipertensi didaptkan polimorfisme gen ACE sebesar 48\%, 29\% dan 23\% masing-masing berupa genotip II, ID, dan DD, seperti terlihat pada gambar 1.

Data ditampilkan sebagai persentase subgrup genotip. II, insersi-insersi. ID, insersi-delesi. DD, delesi-delesi. Dari 100 pasien hipertensi terdapat polimorfisme gen ACE berupa genotip II 48\%, genotip ID 29\%, dan genotip DD $23 \%$.

\section{ACE Gene Polymorphism}

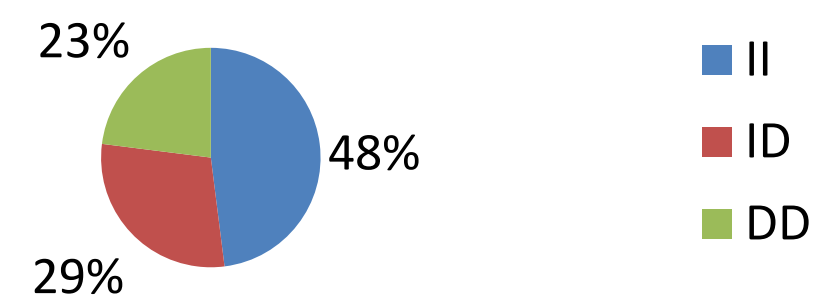

Gambar 1. Polimorfisme gen ACE dari 100 pasien hipertensi. 
Karakteristik dasar dari pasien hipertensi ditampilkan pada tabel 1 . Usia rerata dari pasien adalah 60.17 tahun dimana $68 \%$ sampel adalah perempuan, dengan seluruhnya merupakan suku Jawa. Tidak ditemukan perbedaan yang bermakna dalam hal usia, jenis kelamin, fungsi ginjal, dan kadar kolesterol antara kelompok genotip II/ID dengan genotip DD.

Gula darah puasa dan gula darah 2 jam sesudah makan pada genotip DD signifikan lebih tinggi dibandingkan dengan kelompok genotip II/ID, dengan nilai p 0.024 untuk gula darah puasa, dan
0.046 untuk gula darah 2 jam sesudah makan.

Tidak ditemukan perbedaan tekanan darah yang bermakna diantara kedua kelompok sepertei nampak pada tabel 2.

Pola tekanan darah dipping terlihat sebesar 44.4\% pada genotip II/ID dan $87.5 \%$ pada genotip DD. Tidak terdapat perbedaan yang signifikan di antara kedua kelompok mengenai pola dipping tekanan darah. Sedangkan pola morning surge hanya ditemukan sebesar $2 \%$ pada kelompok genotip II/ID dan $1 \%$ pada genotip DD, juga tidak menunjukkan perbedaan yang bermakna di antara kedua kelompok.

Table 1. Karakteristik Dasar

\begin{tabular}{lccc}
\hline & \multicolumn{2}{c}{ Polimorfisme gen ACE } & \\
\cline { 2 - 3 } Karakteristik & II/ID & DD & p-value \\
\cline { 2 - 3 } & $\mathrm{n}=77$ & $\mathrm{n}=23$ & \\
\hline Usia (tahun) & $60,01 \pm 9,77$ & $60,70 \pm 10,84$ & 0.788 \\
Jenis kelamin & $26(33,8)$ & $6(26,1)$ & 0.661 \\
Laki-laki & $51(66,2)$ & $17(73,9)$ & \\
Perempuan & $29,17 \pm 10,90$ & $27,37 \pm 10,03$ & 0.465 \\
Ureum (mg/dL) & $0,99 \pm 0,32$ & $1,00 \pm 0,36$ & 0.903 \\
Kreatinin (mg/dL) & $5,85 \pm 1,95$ & $5,86 \pm 2,56$ & 0.997 \\
Asam urat (mg/dL) & $93,49 \pm 13,33$ & $108,56 \pm 53,00$ & 0.024 \\
GDP (mg/dL) & $120,12 \pm 29,57$ & $139,83 \pm 67,11$ & 0.046 \\
GD2jPP (mg/dL) & $184,65 \pm 40,65$ & $175,70 \pm 59,53$ & 0.505 \\
Kolesterol total (mg/dL) & $116,17 \pm 30,79$ & $111,48 \pm 40,37$ & 0.611 \\
LDL (mg/dL) & $46,52 \pm 10,41$ & $49,26 \pm 13,49$ & 0.376 \\
HDL mg/dL) & $144,91 \pm 77,35$ & $116,87 \pm 63,4$ & 0.085 \\
\hline Trigliserida (mg/dL) & & & \\
\hline Data ditampilkan sebagai mean $\pm S D$ atau persentase subgrup genotip. or percentage of genotype subgroup. GDP, & \\
gula darah puasa. GD2jPP, gula darah 2 jam post prandial. LDL, low density lipoprotein. HDL, high density \\
lipoprotein.
\end{tabular}

Tabel 2. Perbedaan tekanan darah antara kelompok genotip II/ID dan genotip DD setelah terapi penghambat ACE.

\begin{tabular}{lccc} 
& \multicolumn{2}{c}{ Polimorfisme gen ACE } & \\
\cline { 2 - 3 } Tekanan Darah & II/ID & DD & -value \\
& $\mathrm{n}=18$ & $\mathrm{n}=8$ & \\
\hline Sistolik $(\mathrm{mmHg})$ & $141,45 \pm 16,05$ & $132,05 \pm 19,07$ & 0.248 \\
Diastolik $(\mathrm{mmHg})$ & $85,24 \pm 10,12$ & $78,16 \pm 10,78$ & 0.14 \\
Tekanan Darah Terkontrol & & & 0.216 \\
Ya & $8(44.4)$ & $6(75.0)$ & \\
Tidak & $10(55.6)$ & $2(25.0)$ & \\
\hline
\end{tabular}

Data sebagai mean \pm SD. 
Tabel 3. Pola Ambulatory Blood Pressure Measurement

\begin{tabular}{|c|c|c|c|}
\hline \multirow{3}{*}{ Tekanan Darah } & \multicolumn{2}{|c|}{ Polimorfisme gen ACE } & \multirow{3}{*}{$p$-value } \\
\hline & II/ID & $\mathrm{DD}$ & \\
\hline & $\mathrm{n}=18$ & $\mathrm{n}=8$ & \\
\hline Dipping & & & 0.084 \\
\hline Ya & $8(44,4)$ & $7(87,5)$ & \\
\hline Tidak & $10(55,6)$ & $1(12,5)$ & \\
\hline Morning Surge & & & 1 \\
\hline Ya & $2(11,1)$ & $1(12,5)$ & \\
\hline Tidak & $16(88,9)$ & $7(87,5)$ & \\
\hline
\end{tabular}

Data ditampilkan sebagai mean \pm SD atau persentase subgrup genotip.

\section{Diskusi}

Hasil analisis menunjukkan kadar gula darah puasa dan kadar gula darah 2 jam sesudah makan pada kelompok genotip DD signifikan lebih tinggi dibandingkan kelompok genotip II/ID. Hasil ini serupa dengan penelitian sebelumnya yang menyatakan bahwa subjek dengan genotip delesi yang homozigot memiliki kadar gula darah puasa yang lebih tinggi dibanding subjek dengan genotip insersi yang homozigot ${ }^{6}$ dan kadar gula darah 2 jam sesudah makan lebih tinggi pada genotip DD dibandingkan subjek dengan genotip II/ID. ${ }^{7}$

Sebagai produk akhir dari sistem renin angiotensin, angiotensin II berperan tidak hanya dalam regulasi tekanan darah namun juga status metabolik. Selain itu angiotensin II juga mampu menghambat kerja insulin pada jaringan vaskular dan otot rangka melalui reseptor AT1, mengganggu signaling insulin melalui phosphatidylinositol 3-kinase (PI3K) dan jalur turunannya protein kinase B (Akt). Hambatan ini menurunkan transport gula pada otot rangka, dan menimbulkan gula darah dalam plasma meningkat. ${ }^{8}$ Pandangan lain mengatakan bahwa kondisi ini berhubungan dengan respon katekolamin terhadap kondisi stres yang menyebabkan peningkatan kadar gula darah. ${ }^{9}$ Telah diperkirakan bahwa sebagian dari pasien dengan hipertensi primer mengalami resistensi insulin. Disebutkan pula bahwa di antara pasien hipertensi yang menjalani pengobatan, peningkatan risiko mengalami diabetes onset baru menjadi 2 kali lipat pada pasien yang tekanan darahnya tidak terkontrol. ${ }^{10}$ Temuan pada penelitian ini berbeda dengan hasil penelitian Zhou dkk yang mengemukakan bahwa polimorfisme gen ACE bukan merupakan faktor risiko diabetes mellitus tipe 2; namun studi ini melibatkan subjek hipertensi dengan rentang usia 75-85 tahun. ${ }^{11}$

Tidak terdapat perbedaan yang bermakna dalam hal usia, jenis kelamin, fungsi ginjal, dan total kolesterol di antara kedua kelompok genotip. Hasil ini serupa dengan penelitian Bonnet dkk dengan jumlah sampel 1286 yang menyimpulkan bahwa polimorfisme gen ACE tidak berhubungan usia dan jenis kelamin ${ }^{7}$, namun kontradiktif dengan hasil penelitian lain sebelumnya yang mengatakan bahwa terdapat korelasi antara genotip gen ACE dengan kadar kolesterol total. ${ }^{12}$

Mengenai tekanan darah di antara kelompok genotip II/ID dibandingkan dengan genotip DD tidak ditemukan perbedaan yang signifikan, seperti yang dilaporkan oleh penelitian Larsen $\mathrm{dkk}^{2}$

Pola tekanan darah dipping terlihat pada kelompok genotip II/ID sebesar $44.4 \%$ dan $87.5 \%$ pada genotip $\mathrm{DD}$, namun perbedaan ini tidak bermakna secara statistik. Selain itu pola tekanan darah morning surge juga tidak berbeda signifikan di antara kedua kelompok, yakni sebanyak 2\% pada kelompok genotip II/ID dan $1 \%$ pada kelompok genotip DD. Hasilhasil demikian serupa dengan penelitian sebelumnya yang menyimpulkan bahwa hasil pemeriksaan menggunakan ABPM tidak berbeda bermakna pada genotip dari polimorfisme gen ACE. ${ }^{13}$

\section{Kesimpulan}

Penelitian ini menemukan bahwa pasien hipertensi dengan genotip DD memiliki kadar gula darah yang lebih tinggi dibandingkan dengan genotip II dan ID. Penelitian dengan jumlah sampel yang lebih besar diperlukan untuk lebih merepresentasikan populasi hipertensi.

\section{Daftar Pustaka}

1. Sayed-Tabatabaei FA, Oostra BA, Isaacs A, Van Duijn CM, Witteman JCM. ACE polymorphisms. Circulation research. 2006; 98(9):1123-1133.

2. Agerholm-Larsen B, Nordestgaard BrG, TybjĀ $\mid$ rg-Hansen A. ACE gene polymorphism in cardiovascular disease meta-analyses of small and large studies in whites. Arteriosclerosis, thrombosis, and vascular biology. 2000; 20(2):484-492.

3. Saab YB, Mrouch MA, Gard P. Renin angiotensin system poly- 
morphisms and associated diseases. Pan Arab Medical Journal. 2004; 1:43-48.

4. Li Y-F, Zhu X-M, Liu F, Xiao C-S, Bian Y-F, Li H, et al. Angiotensin-converting enzyme (ACE) gene insertion/deletion polymorphism and ACE inhibitor-related cough: a meta-analysis. PloS one. 2012; 7(6):e37396-e37396.

5. Nagi DK, Foy CA, Mohamed-Ali V, Yudkin JS, Grant PJ, Knowler WC. Angiotensin-1converting enzyme (ACE) gene polymorphism, plasma ACE levels, and their association with the metabolic syndrome and electrocardiographic coronary artery disease in Pima Indians. Metabolism. 1998; 47(5):622-626.

6. Zingone A, Dominijanni A, Mele E, Marasco O, Melina F, Minchella $P$, et al. Deletion polymorphism in the gene for angiotensin converting enzyme is associated with elevated fasting blood glucose levels. Human genetics. 1994; 94(2):207-209.

7. Bonnet F, Patel S, Laville M, Balkau B, Favuzzi A, Monti LD, et al. Influence of the ACE gene insertion/deletion polymorphism on insulin sensitivity and impaired glucose tolerance in healthy subjects. Diabetes care. 2008; 31(4):789-794.

8. Sowers JR. Insulin resistance and hypertension. American Journal of Physiology-Heart and Circulatory Physiology. 2004;
286(5):H1597-H1602.

9. Benigni A, Cassis P, Remuzzi G. Angiotensin II revisited: new roles in inflammation, immunology and aging. EMBO molecular medicine. 2010; 2(7):247-257.

10. Hsueh WA, Wyne K. Renin Angiotensine Aldosterone System in Diabetes and Hypertension. The Journal of Clinical Hypertension. 2011; 13(4):224-237.

11. Zhou Y-F, Yan H, Hou X-P, Miao J-L, Zhang J, Yin Q-X, et al. Association study of angiotensin converting enzyme gene polymorphism with elderly diabetic hypertension and lipids levels. Lipids Health Dis. 2013; 12(1):187.

12. Aziza L, Sjabani M, Haryana SM, Soesatyo MHNE, Sadewa AH. The Relationship of Angiotensin-Converting Enzyme Gene Polymorphism Insertion/Deletion and Hypertension in Yogyakarta Population, Indonesia. Journal of the Indonesian Medical Association. 2011;60(04).

13. Perticone F, Ceravolo R, Cosco C, Trapasso M, Zingone A, Malatesta $\mathrm{P}$, et al. Deletion polymorphism of angiotensinconverting enzyme gene and left ventricular hypertrophy in southern Italian patients. Journal of the American College of Cardiology. 1997; 29(2):365-369. 